\title{
SENSOR FUSION CONTROL SYSTEM FOR COMPUTER INTEGRATED MANUFACTURING
}

\author{
C.M. Kumile ${ }^{1}$ and G. Bright ${ }^{2}$ \\ ${ }^{1}$ Department of Mechanical Engineering \\ Tshwane University of Technology, South Africa \\ kumilecm@tut.ac.za \\ ${ }^{2}$ School of Mechanical Engineering \\ University of KwaZulu Natal, South Africa \\ brightg@ukzn.ac.za
}

\begin{abstract}
Manufacturing companies of today face unpredictable, high frequency market changes driven by global competition. To stay competitive, these companies must have the characteristics of cost-effective rapid response to the market needs. As an engineering discipline, mechatronics strives to integrate mechanical, electronic, and computer systems optimally in order to create high precision products and manufacturing processes. This paper presents a methodology of increasing flexibility and reusability of a generic computer integrated manufacturing (CIM) cell-control system using simulation and modelling of mechatronic sensory system (MSS) concepts. The utilisation of sensors within the CIM cell is highlighted specifically for data acquisition, analysis, and multi-sensor data fusion. Thus the designed reference architecture provides comprehensive insight for the functions and methodologies of a generic shop-floor control system (SFCS), which consequently enables the rapid deployment of a flexible system.
\end{abstract}

\section{OPSOMMING}

Hedendaagse vervaardigingsondernemings ervaar gereeld onvoorspelbare markveranderinge wat aangedryf word deur wêreldwye mededinging. Om kompeterend te bly moet hierdie ondernemings die eienskappe van kosteeffektiwiteit en snelle-respons op markfluktuasies toon. Megatronika streef daarna om meganiese, elektroniese en rekenaarstelsels optimaal te integreer om hoëpresisieprodukte en produksieprosesse daar te stel. Hierdie artikel suggereer ' $n$ metodologie vir toenemende aanpasbaarheid en herbruikbaarheid van 'n generiese rekenaargeïntegreerde vervaardigingsel-beheersisteem deur die gebruik van simulasie en die modellering van megatroniese sensorsisteemkonsepte. Die aanwending van sensors binne die sel fasiliteer datavaslegging, ontleding en multisensordatafusie. Sodoende verskaf die ontwerpte argitektuur insig in die funksie en metodologie van ' $n$ generiese stukwerkwinkelbeheersisteem wat die vinnige ontplooiing van 'n aanpasbare sisteem moontlik maak.

\footnotetext{
${ }^{1}$ The author is enrolled for the PhD in Mechanical Engineering at the School of Mechanical Engineering, University of KwaZulu Natal.
} 


\section{INTRODUCTION}

Globalisation has generated an increasing demand for manufacturing systems to be able to be re-configured quickly to accommodate new varied products, utilising new machines or processes. Gunasekaran [1] states that nowadays businesses are pressured to deal with increased complexities and the challenges of customers demanding high quality, low cost products, higher product variety, small batches, and shorter throughput times. Various strategies have been employed in order to enhance the competitiveness of businesses. These include, but are not limited to, agile manufacturing, computer integrated manufacturing, reconfigurable manufacturing, automation, and mechatronics.

As an engineering discipline, mechatronics strives to integrate mechanical, electronic, and computer systems optimally in order to create high precision products and manufacturing processes (Craig [2]). As an interdisciplinary subject it has now evolved to incorporate optical, communication, and information technologies. In particular, optical sensing and data processing technologies are being integrated at an accelerated rate into mechatronic systems, because these optical-based technologies provide components for high precision, rapid information processing, and smart functions.

Sensor fusion is a method of integrating signals from multiple sources. It allows the extraction of information from several different sources to integrate them into a single signal or information. In many cases sources of information are sensors or other devices that allow for the perception or measurement of a changing environment. Information received from multiple sensors is processed using 'sensor fusion' or 'data fusion' algorithms. These algorithms can be classified into three different groups: first, fusion based on probabilistic models; second, fusion based on least-squares techniques; and third, intelligent fusion. The probabilistic model methods are Bayesian reasoning, evidence theory, robust statistics, and recursive operators. The least-squares techniques are Kalman filtering, optimal theory, regularization, and uncertainty ellipsoids. The intelligent fusion methods are fuzzy logic, neural networks, and genetic algorithms.

This paper will present the development of a mechatronic sensory system (MSS) and the application of predefined algorithms/heuristics for the solution of decisionmaking activities within the CIM cell, utilising the mechatronics design methodology. Data capture methodology is highlighted to present pallet navigation, based on the sensor/data fusion method for signals received from a single sensor scanner mechanism and bar code system, as well as modular conveyor sensors. The fusion process allows for more efficient navigation and depiction of the pallet within the CIM cell.

The rest of the paper is organized as follows. First a description to the term 'mechatronics' is provided (Section 2), and then the research experimental testbed is provided (Section 3). The mechatronic sensory system concept is then provided (Section 4). The graphic user interface and conveyor control system is elaborated (Section 5). The aspects of multi-sensor data fusion and Kalman filters are provided (Section 6). Finally, the paper's conclusions and summary are presented (Section 7). 


\section{FUNDAMENTALS OF MECHATRONICS}

According to Bradley [3], although there are many definitions of mechatronics, there is still considerable debate on what it really means. Researchers have provided numerous descriptions; however, none of them can describe mechatronics completely since the field is continually evolving. The portmanteau word 'mechatronics' was first coined by Mr Tsetsuro Mori, a senior engineer at the J apanese company Yaskawa in 1969, as a combination of 'mecha' from mechanisms and 'tronics' from electronics (Harashima, and Tomizuka [4]). Yaskawa was granted the trademark rights on the word 'mechatronics' in 1971 to describe the philosophy in the design of electro-mechanical products to achieve optimum systems performance (J apan Trade Mark [5], J apan Trade Registration No. 946594 [6]).

Between the late 1980s and early 1990s, a number of attempts were made to provide a definition of mechatronics. For example, the EEC/IRDA Working Party on mechatronics wrote: "Mechatronics is the synergetic combination of precision mechanical engineering, electronic control and systems thinking in the design of products and processes" (Acar and Parkin [7]). An alternative definition took this form: "Mechatronics represents an approach to the design of engineering systems which involves the integration of mechanical engineering, electrical and electronic engineering with software engineering and computer based technology at all levels of the design process" (Craig [2]; refer to Figure 1). The objective of mechatronics is to design better products and production systems by making optimal use of the possibilities of mechanics, electronics, and software.

This approach is not new. In fact, many companies have been implementing mechatronic concepts for many years. However, awareness of mechatronics as a competitive edge in the design of products and production systems is growing. Today, cost-effective electronics, microcomputers, and digital signal processors have brought space technology to appliances and consumer products. Systems with precision sensors and actuators have increased performance by several orders of magnitude over what was once possible. There are many designs where electronics and controls are combined with mechanical components; but with little synergy and poor integration, they become just a marginally useful, error-prone, expensive conglomeration. Synergism and integration in design set a mechatronic system apart from a traditional, multidisciplinary system.

Control systems for manufacturing cells in today's industry have received significant attention in recent years (Verduzco et al. [8]), but they have been found to have the following inter-related characteristics:

- $\quad$ Long time required for system development and maintenance, which ultimately cost too much.

- Low quality - that is, the functions, behaviour, or properties do not correspond to actual needs.

- $\quad$ SFCS are often not flexible enough to adapt to the increasingly frequent changes required as a result of rapid developments in technology, products, and machining and assembly processes. 
To meet CIM cell performance specifications, the controller should include different strategies for each individual constituent part's operating condition, adaptive behaviour to react to uncertainty, and the capability to co-ordinate distributed MSS and individual CIM cell components' controllers to implement multiple tasks in a coherent way (Kumile and Bright [9]).

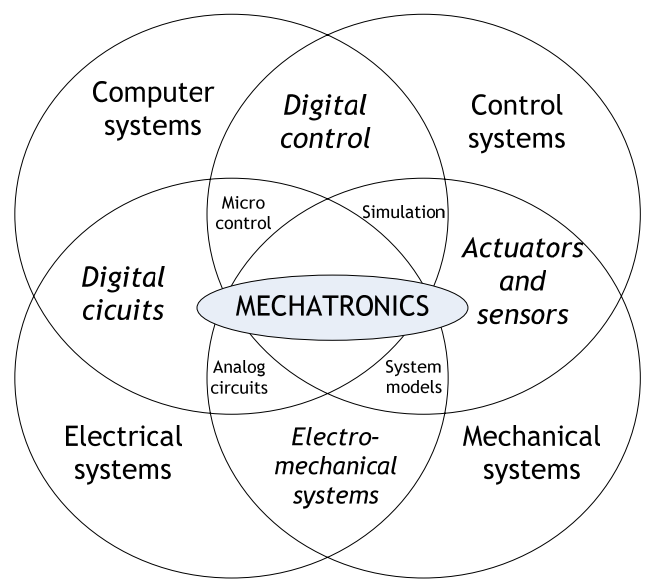

Figure 1: Mechatronics: Synergism and integration through design (Craig [2])

This paper will demonstrate the usefulness of the MSS approach to the synthesis of $\mathrm{CIM}$, stressing such features as universality, synergistic design, computational efficiency, and high system performance. The research project will provide knowledge (design guidelines related to the integrated design of a CIM system) about how to improve SFCS utilising sensory data stemming from different sensors and sensor fusion, so that the overall performance of SFCS is increased at a lower cost.

\section{EXPERIMENTAL SET-UP}

The University of KwaZulu-Natal CIM cell in the Mechatronics and Robotics Research Group $\left(M R^{2} G\right.$ ) laboratory is shown in Figure 2. It comprises:

- $\quad$ A single aisle automated storage and retrieval system (AS/ RS) in which raw materials, work in progress (WIP), and finished goods are stored. The storage and retrieval (S/R) machine delivers pallets/goods from the conveyor belt into storage, or retrieves pallets/goods from storage and delivers them to the conveyor belt.

- A modular roller conveyor belt is used to transport parts among the different workstations within the CIM cell. 
- $\quad$ A PC-based PUMA robot and indexing devices are used to load and unload components on the conveyor belt.

- $\quad$ An automated guided vehicle (AGV) is used for parts delivery operating in an omni-directional manner. This system allows the AGV to be integrated with a conveyor system, such that there is a physical mating between the AGV and part conveyor. A path, made of a black metallic strip lined on the ground, enables the AGV to follow a particular path as it connects other components of the CIM cell.

- A MAHO MH 400C milling machine with a CNC Heidenhain controller is utilised to process components.

- A co-ordinate measuring machine (CMM) station adds flexible quality control to the cell by reducing the need for fixturing and special gauges during inspection. As the CMM is computer-controlled, inspection data can be stored and inspection programmes can be executed automatically.

- $\quad$ An automated visual inspection system (AVIS) visually monitors the quality of manufactured parts throughout the manufacturing cycle.

CIM cell components comprise PC-based controllers that are linked to a host computer, which can be remotely activated by an operator via the Internet.

\section{MECHATRONIC SENSORY SYSTEM}

To enable conveyor segment operation, tracking, and exact positioning of the pallet on the conveyor belt, a series of infra-red (IR) emitter and receiver sensors are installed in strategic positions on the conveyor. The light sensors used are the paired emitter and receiver type, which use a modulated IR beam. The sensor pairs that are are positioned at the ends of conveyor segments and at points requiring exact positioning within the conveyor belt. At the extreme ends of the conveyor, sensor pairs are placed such that the pallet's movement on the conveyor would is be recorded as it blocks the light beams of the sensors (Figure 3).

Twenty- four (24) pairs of the light sensor circuits are used and interfaced with the PC30GA series 1/O board (developed by Eagle Technology) 1/O board for data acquisition and procession along the conveyor segments, as shown in Figure 4 . The programmable digital input/ output card includes the driver software callable form to Visual Basic software allowing for easy access to the ports. The $1 / 0$ card interfaces with peripheral devices via an interconnecting harness that allows fast cable assembly and termination. This carries signals to and from the port's power supplies. The A photographic diagram for of the emitter and-receiver light sensor circuits is shown in Figure 5. 


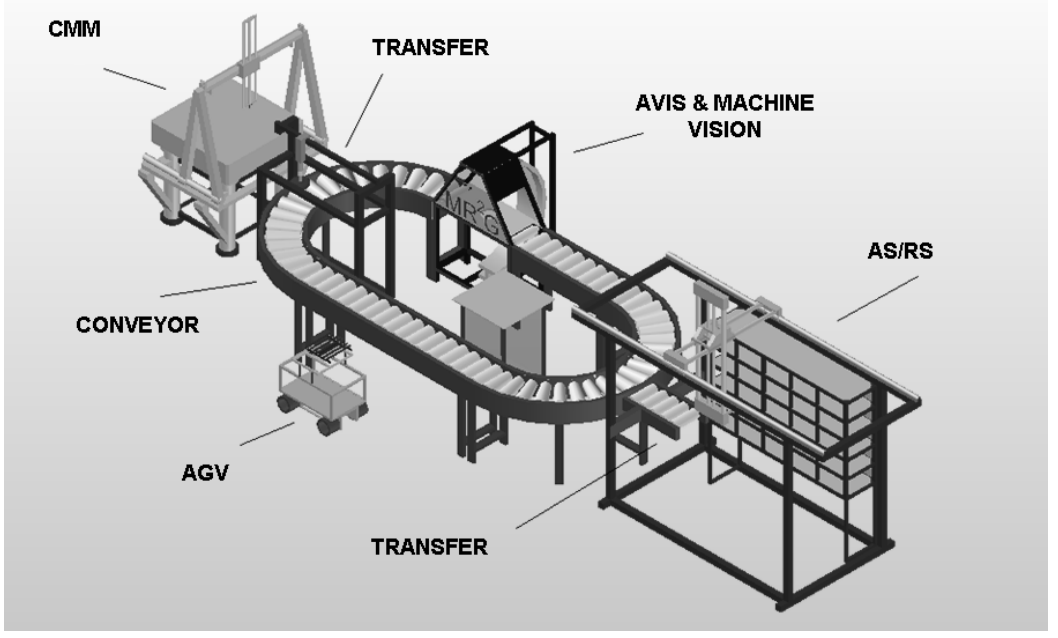

Figure 2: University of KwaZulu- Natal CIM cell layout

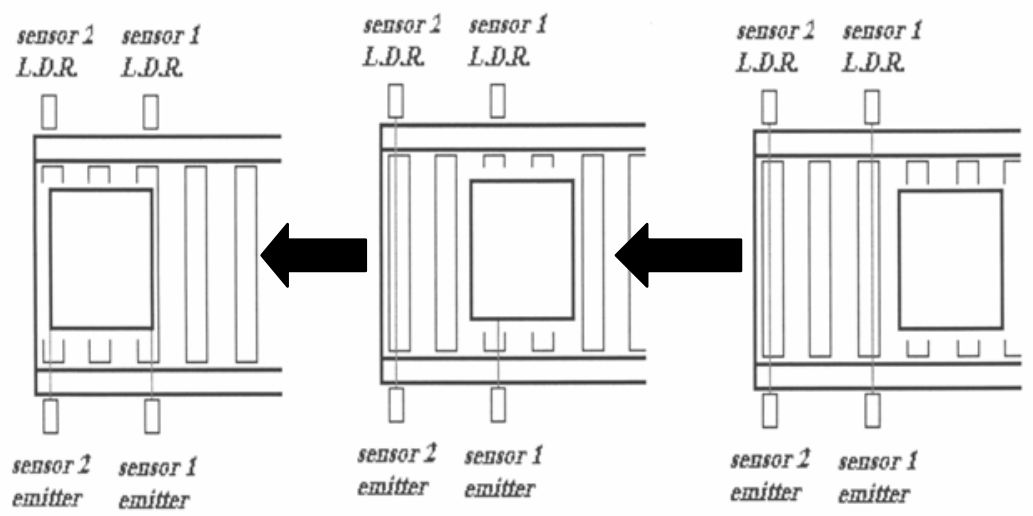

Figure 3: IR pairs configuration in the conveyor system 


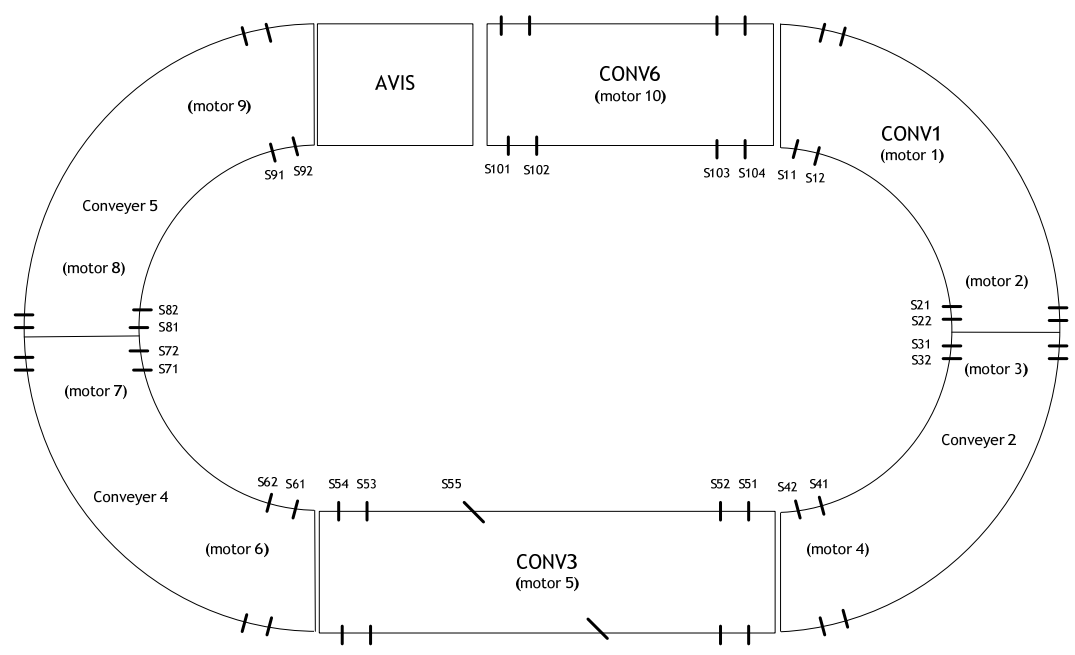

Figure 4: Sensor numbering within the Conveyor System

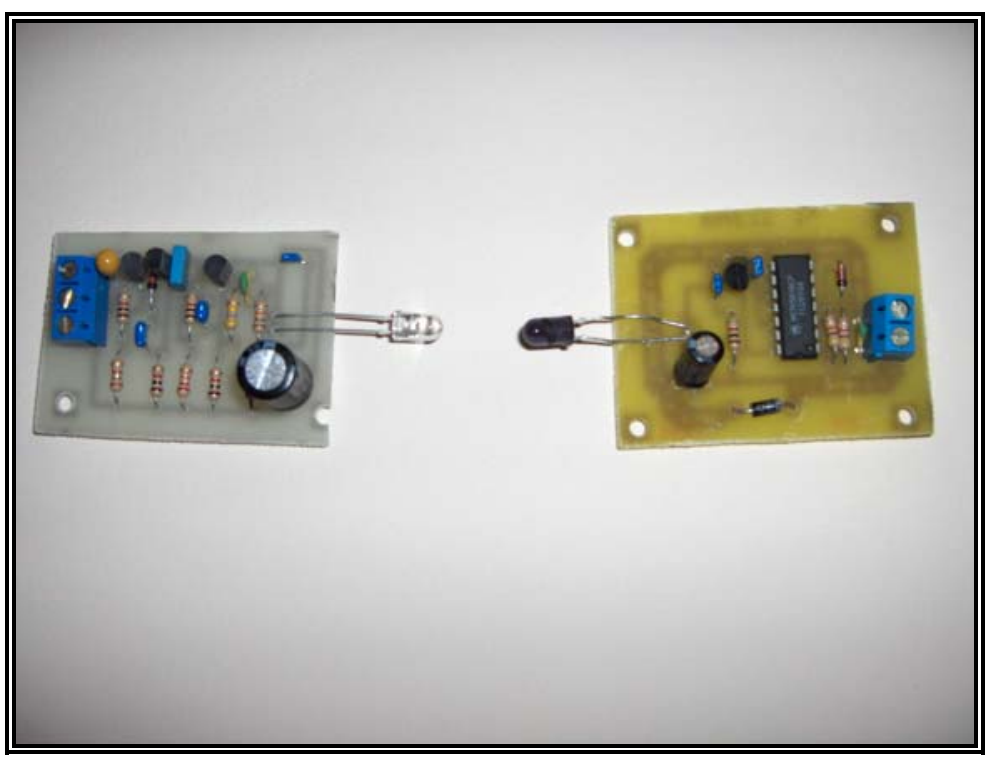

Figure 5: Emitter and receiver light sensor circuits 


\section{THE CONVEYOR CONTROL SYSTEM}

The Visual Basic (VB) 6, Deitel and Deitel, [10] software program (Deitel and Deitel [10]), which is consistent compatible with the standard Microsoft Wwindows operating environment, was used in the experiment to provide an interface between the hierarchical controller and the modular conveyor system, as well as sensors. The manual control allows for individual conveyor motor drives to be turned on or off, and their direction of rotation changed in real -time. On start up, the operator is presented with the Conveyor Operating Form (COF), which is the main control window of the program that contains all menus and short cuts for the user to navigate around various options (Figure 6).

The COF comprises of the information and the simulation screen. The information screen provides information such as the board type, the value of the base address, the number of digital inputs and output ports available and the ability for configuration of a port for input or output.

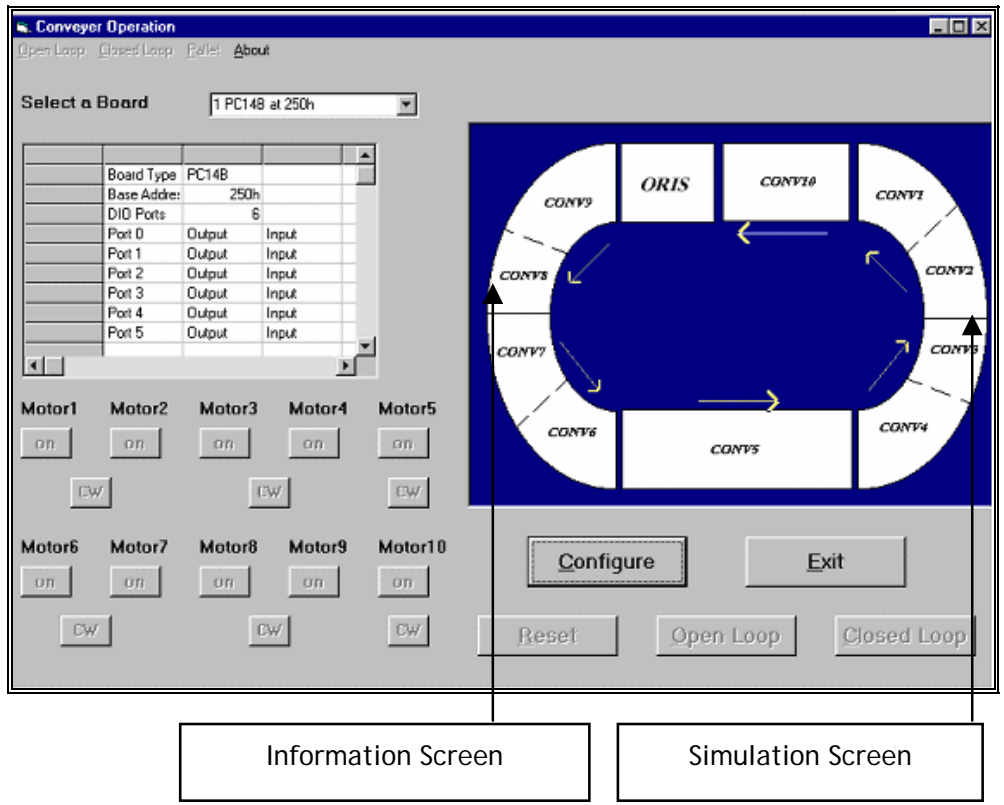

Figure 6: Conveyor operating form

The simulation screen provides a graphical view of the conveyor initially in a neutral position, and can be executed to provide an analysis inof pallet mobility (Figure 7). The simulation screen shows modular conveyer segments in its their neutral state without the arrows depicting the direction that a pallet would follow if athe motor were to be switched on. 
The simulation provides an easy check for the user to keep track of all events. It offers a real- time update of the state of the motors (on/ off), their directions of motion (clockwise/counter-clockwise ([CW or CCW)]) and the position of the pallet as it makes its journey around the conveyer segment that is being powered by it. The direction of pallet movement, should a motor be activated, is indicated by an arrow. By choosing the 'Pallet recognition ON' command on the Pallet menu (or the short cut Shift +Ins), the simulation shows the pallet movement along the conveyer.

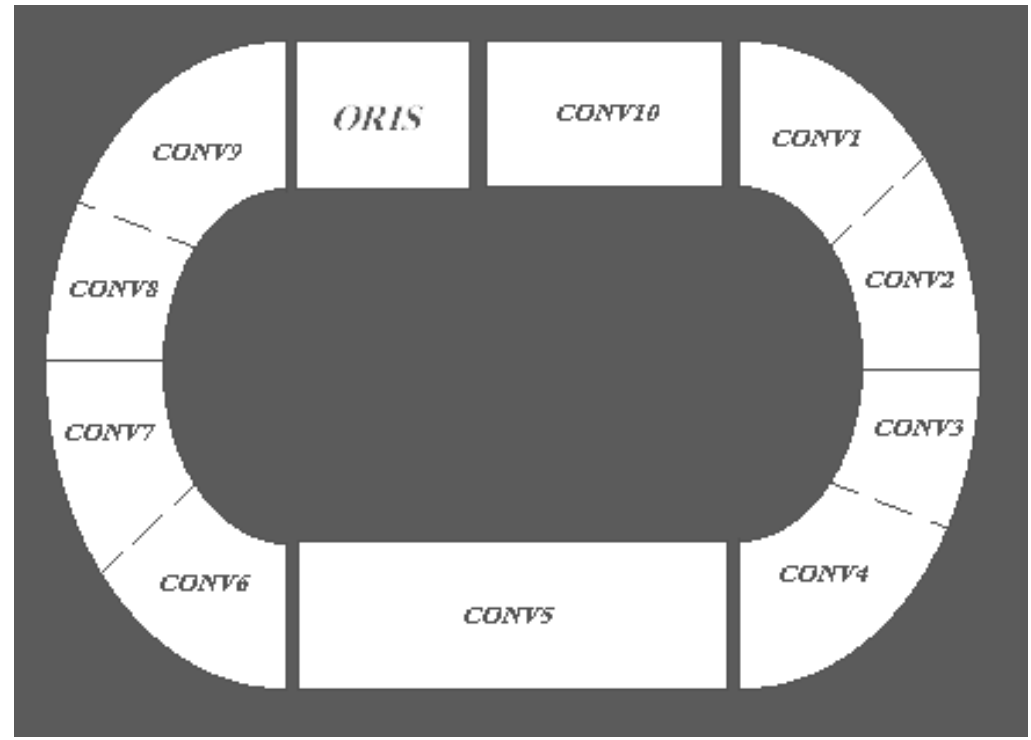

Figure 7: Conveyor segments of the MSS aApparatus

An orange solid orange pallet is used to show fixed positions (when both sensors in a pair both see the pallet), and while a transparent rectangle is seen when shows that the pallet is between sensors on a conveyer segment. Thus the fixed position simulations are of a closed loop nature, while the indeterminate state of the pallet between the sensors is an open loop. The Pallet Recognition command can be deinactivated by clicking on the 'Pallet recognition OFF' command on the pallet menu. The pallet position and movement throughout the conveyor segments can be determined and depicted in frames, as shown in Figure 8.

The closed loop control system offers pre-programmed routes for pallet transportation around the conveyor. The operation uses feedback from twelve infra-red sensors strategically placed around the conveyor track to switch on or off the necessary conveyor segments on or off. The sensors also update the pallet movements on keep the simulation screen updated of the pallet movements. There is an open loop control feature to serve as a backup system in case for the failure of the closed loop system fails. 


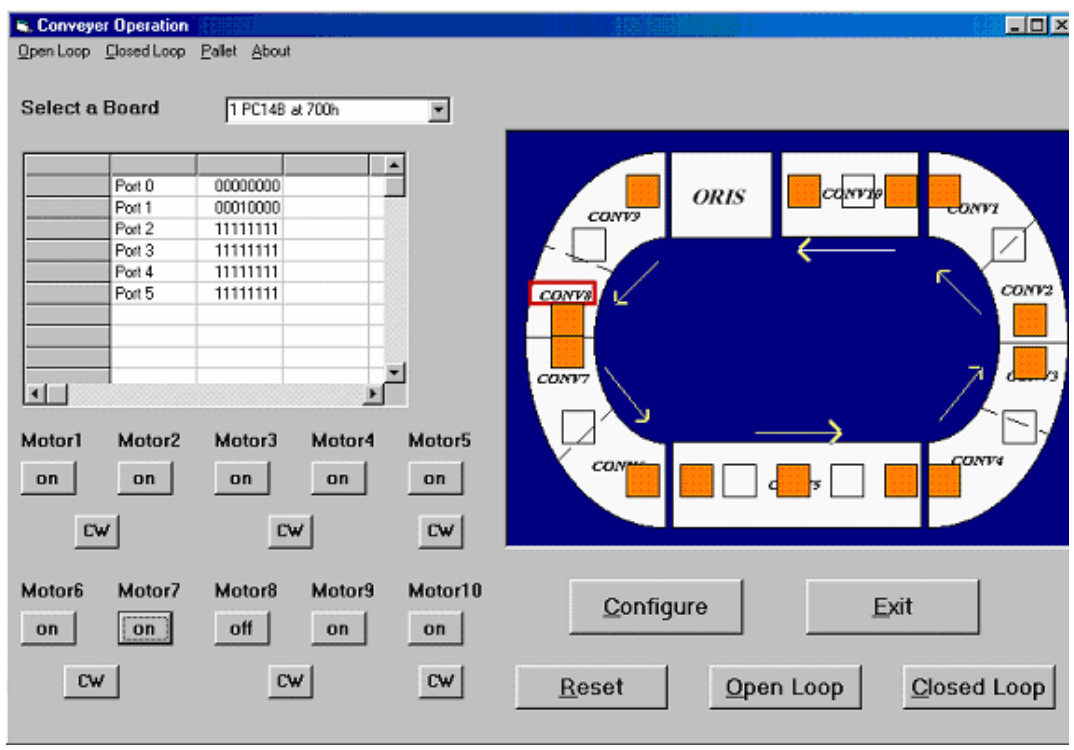

Figure 8: Pallet depiction and recognition

\subsection{Manual Control}

This option gives the operator complete control of the conveyer set-up in real-time. Individual motors can be switched ON or OFF and their respective directions changed by pressing control buttons. The motor numbering does coincides with the conveyer numbering. Thus clicking on the 'ON' button of motor five will switch on conveyer segment five in a default direction corresponding to the pallet moving in a counter-clockwise direction. The manual control button's labels state the action that will occur should a particular button be clicked on. Thus on configuration, the 'ON' buttons are enabled since no motors require to being switched off. By pressing an 'ON' button, a motor is switched on and the corresponding 'OFF' button for that motor is displayed. As can be seen from Figure 9, it is easy to see at a glance which motors are on or off and their respective directions. In this example, motor 10 and motor 1 have been switched on, and both their directions changed to clockwise.

\subsection{Closed loop control}

The closed loop control (CLC) offers four pre-programmed routes for the transportation of a pallet around the conveyer. The operation uses feedback from the twenty-five infra-red sensors mounted around the track to switch on or of the necessary conveyer segment on or off, so that the task is performed in the most efficient manner. The sensors also keep the simulation screen updated with the pallet's movements. The closed loop control form, (Figure 10), was activated by pressing the 'Closed Loop' button. 


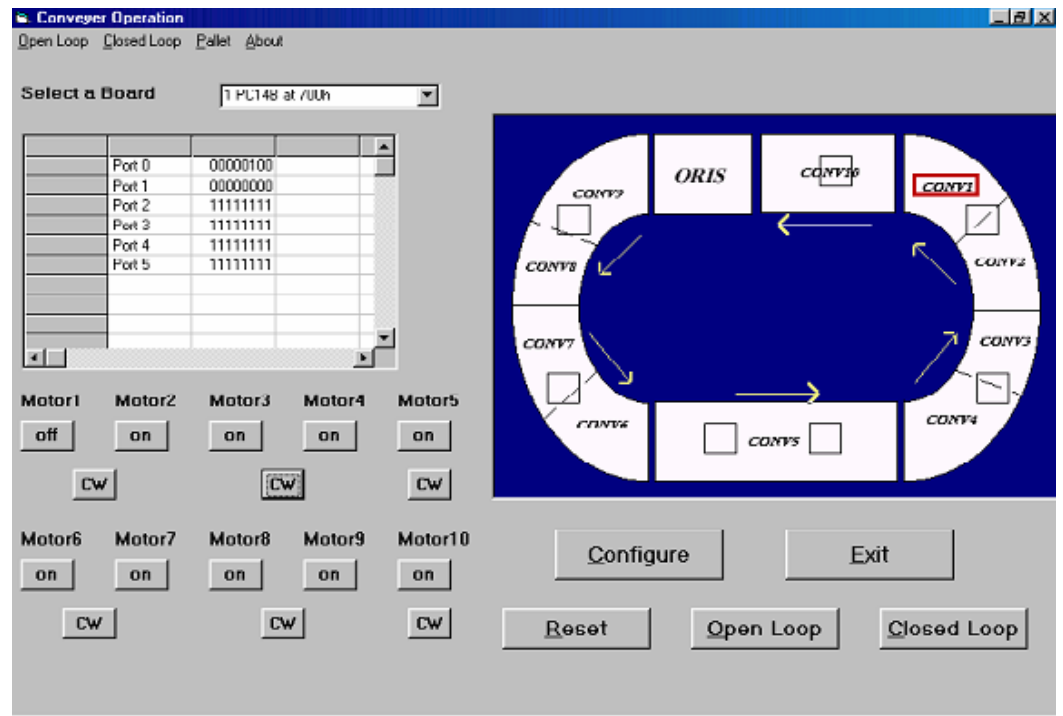

Figure 9: Manual control operation

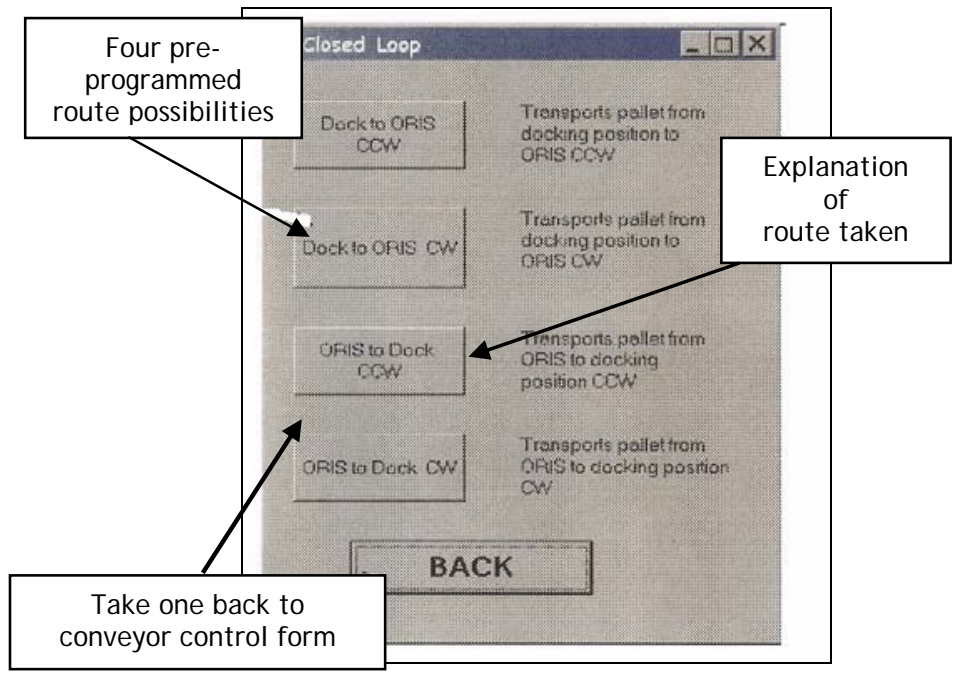

Figure 10: Closed loop control form 
The following buttons may also be activated through the 'Closed Loop' menu command situated at the top of the conveyor control form:

\begin{tabular}{|c|c|c|c|}
\hline Button ILabel & Menu ILabel & Short cut & Description \\
\hline Dock to ORIS CCW & Dck-ORIS-CCW & $\mathrm{F} 1$ & $\begin{array}{l}\text { Transports pallet from } \\
\text { docking position to ORIS } \\
\text { counter- clockwise }\end{array}$ \\
\hline Dock to ORIS CW & Dck-ORIS-CW & $\mathrm{F} 2$ & $\begin{array}{c}\text { Transports pallet from } \\
\text { docking position to ORIS } \\
\text { clockwise }\end{array}$ \\
\hline $\begin{array}{c}\text { ORIS to Dock } \\
\text { CCW }\end{array}$ & ORIS-Dck-CCW & F3 & $\begin{array}{l}\text { Transports pallet from } \\
\text { ORIS to docking position } \\
\text { counter- clockwise }\end{array}$ \\
\hline ORIS to Dock CW & ORIS-Dck-CW & F4 & $\begin{array}{c}\text { Transports pallet from } \\
\text { ORIS to docking position } \\
\text { clockwise }\end{array}$ \\
\hline
\end{tabular}

Table 1: Path for closed loop control

\subsection{Open loop control}

The open loop control (OLC) feature is a back-up system should the CLC feature fail. Such failure could be the result of broken or misaligned light sensors, an irregular work piece larger than $300 \mathrm{~mm}$ in width, or an environment that scatters the infrared beam of the light sensors. The OLC feature performs exactly the same preprogrammed transportation movements as the CLC command, except that there is no corrective feedback from the sensors should something go wrong. All actions are performed using a series of delays and timers that are based on the average time taken for a pallet to traverse a particular conveyer segment, plus an added safety margin. The open loop control form (see Figure 11) can be activated by pressing the 'Open Loop' button.

\section{MULTI-SENSOR DATA FUSION}

Multi-sensor data fusion is the process of combining data and knowledge from different sensor sources with the aim of maximising the useful information content. It improves reliability or discriminating capability, while offering the opportunity to minimise the data retained, (Fraden, [11]). Figure 12 shows an overview of considerations which that characterise data fusion applications, dividing the domain into three overlapping regions, (Hall and Llinas [12]):

- Pre-processing: data reduction

- Data alignment and correlation: Interpolation and spatial or temporal correlation

- Post-processing: combination of mathematical data and knowledge, decision making 


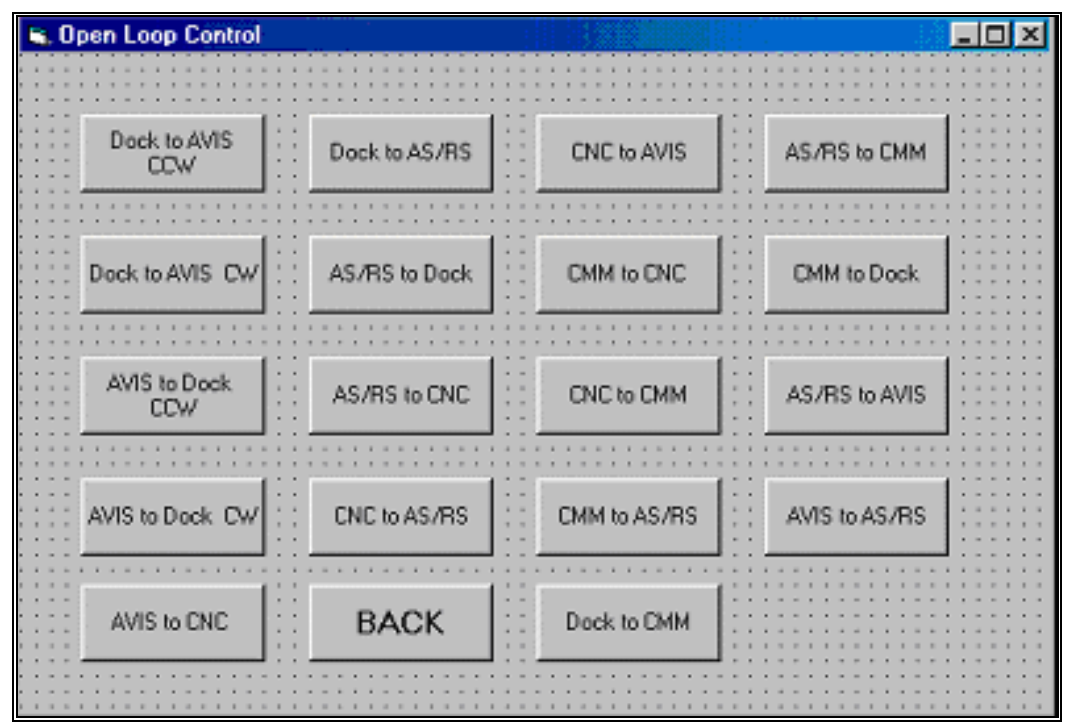

\section{Figure 11: Open loop control form}

Pre-processing

Rect. And elliptical gating

Linear and Non-linear PCA

FFT, Cepstrum, Enveloping, Thresholding

Wavelets

Image Processing
Data allignment

Euclidian, Minkowsky, Manhattan, Mahalanobis, distance metrics

Correlation metrics

Figure of Merit

Least square, Mean square error, maximumlikelihood

Kalman filtering

Parametric templates, Clustering, Neural Networks, Voting, Entropy, Image Algebra

\section{Post-processing}

Classical inference: Maximum aposteriori, Neyman-Pearson, Minimax, Baye's cost

Bayesian Dempster-Shafer, Generalized Evidence

Voting, Consensus, Scoring

Fuzzy logic, Logical templates, Expert systems

Figure 12: Data fusion applications 
In this research, information pertaining to the class state of the pallet was derived from led LED pair sensors, bar code and scanner sensors, and from a digital camera. The position estimator is based on an extended Kalman Filter (EKF) that requires a system model of the pallet motion to be defined. Formulation of models to closely represent actual vehicle behaviour closely is the first step to achievinge accurate and consistent state estimates.

\subsection{The Kalman Filter}

In stochastic state estimation problems, the dynamic system is governed by the following equations:

$$
\begin{aligned}
& x(k+1)=F(k) x(k)+G(k) u(k)+w(k) \\
& z(k)=H(k) x(k)+v(k)
\end{aligned}
$$

where $x(k)$ is the state vector at discrete time step, $z(k)$ is the measurement vector, $u(k)$ is the control input.

The random variables $w(k)$ and $v(k)$ represent the process and measurement noise, respectively, which are white and Gaussian with a covariance matrices $Q(k)$ and $R(k)$, respectively, and are also uncorrelated with each other. In the presence of input and measurement noise, it is not possible to let the state estimation error converge to zero. The stochastic estimation problem is to find the optimal, leastsquare estimate of the state based on the output measurement sequence.

The Kalman Filter estimation algorithm satisfies two statistical conditions to achieve this task: the expected value of the state estimate is equal to the expected value of the state, and the expected value of the square of the estimation error is minimized (Durrant-Whyte [13]). The Kalman Filter estimates a state at some time-step, and then obtains feedback in the form of measurements corrupted by noise. The algorithm involves two steps: prediction and correction.

\section{1) Prediction}

$$
\begin{aligned}
& \hat{x}(k+1 \mid k)=F(k) \hat{x}(k \mid k)+G(k) u(k) \\
& P(k+1 \mid k)=F(k) P(k \mid k) F(k)^{\prime}+Q(k)
\end{aligned}
$$

where $\hat{x}(k+1 \mid k)$ given in Equation 6.3 is the a priori state estimate, and $P(k+1 \mid k)=E\left[(x(k+1)-\hat{x}(k+1 \mid k))(x(k+1)-\hat{x}(k+1 \mid k))^{\prime}\right]$ is the a priori estimation error covariance.

2) Correction

$$
\begin{aligned}
& K(k+1)=P(k+1 \mid k) H^{\prime}(k+1)\left[H(k+1) P(k+1 \mid k) H^{\prime}(k+1)+R(k+1)\right]^{-1} \\
& \hat{x}(k+1 \mid k+1)=\hat{x}(k+1 \mid k)+K(k+1)[z(k+1)-H(k+1) \hat{x}(k+1 \mid k)]
\end{aligned}
$$


$P(k+1 \mid k+1)=P(k+1 \mid k)-K(k+1) H(k+1) P(k+1 \mid k)$

The first task during the correction step is to compute the Kalman Ffilter gain $\mathrm{K}(\mathrm{K}+1)$ given in Equation 6.5. The next step is to generate an updated, a posteriori state estimate according to Equation 6.6 by incorporating the measurement $z(k+1)$. The final step is to obtain an a posteriori error covariance estimate via Equation 6.7 .

A measurement model which that describes the characteristics of the sensor measurements and their relationship with the plant states is needed in the state update. Two major sources of sensory measurements are considered: the temporary absolute position measurements from a landmark-based local reference system are fused with the periodically sampled odometry measurements from the emitter/receiver sensor pairs. The characteristics of the measurements must be accurately modelled so that the filter can exploit the different strengths of the measurements in the fusion process. Odometry measurements are pre-filtered to remove corrupted observations, and redundant odometry measurements are used to suppress noise and improve estimation accuracy. In addition, a method is proposed to constantly calibrate constantly the LED's resolution, to allow odometry measurements to adapt to the varying load and friction conditions of the pallet.

The system and measurement models must be defined in real time at the start of each estimation cycle, depending on the manoeuvres and the type of measurements available. Once the model is selected, the EFK provides a set of recursive equations to minimise the sum of squares of the error in the state estimation.

\section{CONCLUSIONS}

This paper describes the procedures needed to achieve flexibility of a CIM cell utilising sensors. A system control design model for the operation of the conveyor belt segments operation and the definition of data from a bar code utilizing a scanner is also described. The data from the bar code denote the work-piece path, manufacturing process flow, and resource behaviour. This paper has outlined the theoretical development of an adaptive estimator using a Kalman fFilter to estimate the position, orientation, and velocity of a work piece pallet with substantial load variations. It has demonstrated the fusion of odometry measurements with absolute position measurements from a landmark-based local reference system to obtain an optimal estimate of the pallet states.

The framework has been created that defines a formalisation of shop-floor control using sensors previously missing in manufacturing research. The contribution is in the ease and the elegance that the concept provides to finite state/automata activities as well as the production engineering elements such as planning, scheduling, and process plan representation within a CIM cell. 


\section{REFERENCES}

[1] Gunasekaran, A.S., 1999, Agile manufacturing: Framework for research and development, International J ournal of Production Economics, vol. 62, No.1, pp 87-105.

[2] Craig C. K., 2001, Mechatronics in university and professional education: Is there anything really new in mechatronics education? IEEE Robotics and Automation Magazine, Vol. 8, No. 2.

[3] Harashima, F. and Tomizuka, M., 1996, Mechatronics - what is it, why, and how? An Editorial, IEEE/ ASME Transactions on Mechatronics, Vol. 1.

[4] Bradley, D.A., 1997, The what, why and how of mechatronics, Engineering Science and Education J ournal, 6(2), pp:81-88.

[5] J apan Trade Mark Kohhoku, 1971, Class 9, Shou 46-32713,46-32714.

[6] Japan Trade Registration, 1972, No. 946594.

[7] Acar, M. and Parkin, R.M., 1996, Engineering education for mechatronics, IEEE Transactions on Industrial Electronics, 43(1), pp 106-112.

[8] Verduzco et al., 2001, Information-based inspection allocation for real-time inspection systems, : J ournal of Manufacturing Systems, 20(1) pp 13-22.

[9] Kumile, C.M. and Bright, G., 2000, Modeling and developing a real-time mechatronics shop floor control systems for computer integrated manufacturing, Proceedings of the $7^{\text {th }}$ Mechatronics and International Conference, Atlanta, USA. (In CD ROM).

[10] Deitel, H.M., Deitel, P.J., and Nieto T.R., 1999, Visual Basic 6: How to program, Prentice Hall, Upper Saddle River, NJ .

[11] Fraden, J. 1996, Handbook on modern sensors, published by SpringerVerlag.

[12] Hall, D.L., and Llinas, J., 2001, Handbook of multisensor data fusion, CRC Press

[13] Durrant-Whyte, H. F., 1996. An autonomous guided vehicle for cargo handling applications, International J ournal of Robotics Research, 15(5), pp 407-440. 